\title{
IDENTIFIKASI BAKTERI PATOGEN PENYEBAB PENYAKIT PURPLE SYNDROME PADA KARANG FUNGIA DI PULAU HARI SULAWESI TENGGARA
}

\section{Identification of Pathogenic Bacteria as Purple Syndrome Causative Agent in Fungia Corals on Hari Island, Southeast Sulawesi}

\author{
Ratna Diyah Palupi, Baru Sadarun, Paiga Hanurin Sawonua* \\ Jurusan IImu Kelautan Fakultas Perikanan dan IImu Kelautan Universitas Halu Oleo Kampus Hijau Bumi \\ Tridharma Anduonohu, Kendari 93232 \\ *Email: paiga_sawonua@uho.ac.id
}

\begin{abstract}
Nowadays coral disease is one of the causes of damage to coral reefs in Indonesia. Causative agents were found for some types of coral disease. This study aims to identify the type of pathogenic bacteria that cause purple syndrome which attacks Fungia corals. The study was conducted using descriptive exploratory methods. Corals infected with purple syndrome were collected on Pulau Hari, Southeast Sulawesi, through scuba diving. Then, microbiological analysis was carried out which included isolation using the scatter method, purification using a scratch method, a challenge test (antagonistic), a Koch Postulate test, and DNA analysis of putative bacterial isolates. Results showed that 5 bacterial isolates lived in symbiosis with the corals infected with purple syndrome (PSMH1, PSMH2, PSMH3, PSMH4, and PSMH5). Based on the Koch postulate test, 2 bacterial isolates which were pathogenic were obtained, namely PSHM2 and PSHM4 isolates. These bacteria infected the test corals with the characteristics of coral skeleton damage and coral bleaching (dead). Based on biomolecular testing, the two isolates were members of Enterobacter cloacae with a 99\% similarity level.
\end{abstract}

Keywords: Coral disease, Enterobacter cloacae, Fungia coral, Hari island, Purple syndrome

\begin{abstract}
ABSTRAK
Saat ini penyakit karang menjadi salah satu penyebab kerusakan terumbu karang di Indonesia. Penyebab pembawa untuk beberapa jenis penyakit karang sudah ditemukan. Penelitian ini bertujuan untuk mengidentifikasi jenis bakteri patogen penyebab penyakit purple syndrome yang menyerang karang Fungia. Penelitian dilakukan menggunakan metode deskriptif eksploratif. Sampel karang yang terinfeksi purple syndrome diambil di Pulau Hari, Sulawesi Tenggara, melalui scuba diving. Selanjutnya, analisis mikrobiologi dilakukan yang meliputi isolasi menggunakan metode sebar, purifikasi menggunakan metode gores, uji tantang (antagonistik), uji Postulat Koch, dan analisa DNA isolat bakteri yang diduga bersifat patogen. Hasil penelitian menemukan 5 isolat bakteri yang bersimbiosis dengan karang yang terinfeksi penyakit purple syndrome (PSMH1, PSMH2, PSMH3, PSMH4, dan PSMH5). Berdasarkan uji postulat Koch, 2 isolat bakteri yang bersifat patogen didapatkan, yaitu isolat PSHM2 dan PSHM4. Bakteri tersebut menginfeksi karang uji dengan ciri kerusakan skeleton karang dan pemutihan karang (mati). Berdasarkan uji biomolekuler kedua isolat tersebut merupakan anggota Enterobacter cloacae dengan tingkat kemiripan $99 \%$.
\end{abstract}

Kata Kunci: Enterobacter cloacae, karang Fungia, penyakit Karang, pulau Hari, Purple syndrome 


\section{PENDAHULUAN}

Ekosistem terumbu karang merupakan ekosistem yang memiliki tingkat asosiasi paling kompleks diantara dua ekosistem lainnya, yaitu padang lamun dan hutan mangrove. Beberapa hewan, baik itu hewan tingkat rendah maupun tingkat tinggi berinteraksi membentuk sebuah ekosistem yang stabil dan seimbang. Akan tetapi jika ekosistem biota karang tersebut mengalami ketidakseimbangan maka dapat menurunkan kualitas sumber daya yang ada pada habitat tersebut. Terumbu karang merupakan rumah bagi hewan-hewan laut yang secara ekonomi bernilai tinggi. Kerusakan pada terumbu karang tersebut menyebabkan kehidupan biota laut ikut terganggu. Salah satu kerusakan yang dapat terjadi pada hewan karang adalah penyakit karang yang ditimbulkan oleh mikroorganisme, baik itu bakteri, virus, maupun jamur (de Castro et al. 2010).

Selama ini sebagian besar kerusakan terumbu karang disebabkan oleh faktor antropogenik yang didominasi oleh kegiatan perikanan yang tidak ramah lingkungan (bom, bius, serta metode penangkapan ikan yang salah). Timbulnya penyakit karang juga harus diwaspadai sebagai penyebab kerusakan terumbu karang pada suatu perairan dan harus diwaspadai sebagai sumber degradasi terumbu karang (Sabdono et al. 2014; Kellogg et al. 2014; Randal et al. 2016). Beberapa peneliti menemukan bahwa prevalensi penyakit karang di perairan Indonesia sudah menunjukkan pada tingkat mengkhawatirkan. Penelitian Abrar et al. (2012) di Perairan Lembata NTT menyebutkan nilai prevalensi penyakit dan gangguan kesehatan karang sampai dengan 42\%. Lebih lanjut Palupi et al. (2018) dalam penelitiannya di Perairan Kessilampe, Kendari, Sulawesi Tenggara menunjukkan bahwa nilai prevalensi penyakit karang sudah mengkhawatirkan, yaitu sebesar $15 \%$ dan gangguan kesehatan karang sebesar 14\%. Bahkan hasil penelitian Sabdono et al. (2015) menyebutkan bahwa prevalensi penyakit karang di perairan Pulau Panjang, Jepara Jawa Tengah telah mencapai $74,37 \%$. Penyakit karang di Florida Amerika Serikat sudah menjadi perhatian utama para peneliti dimana mikroorganisme patogen menjadi penyebab utama degradasi terumbu karang di perairan tersebut (Kellogg et al. 2014).
Banyak faktor yang dapat memicu keberadaan bakteri patogen yang bersimbiosis dengan hewan karang. Faktor tersebut antara lain faktor lingkungan (kenaikan suhu, pengkayaan nutrien, polusi dari sampah plastik, limbah industri, maupun limbah rumah tangga), keberadaan bakteri di perairan laut, serta imunitas dari biota karang dalam menghadapi serangan patogenitas bakteri (Randall et al, 2016; Chávez et al., 2018). Salah satu mikroorganisme yang telah diidentifikasi sebagai penyebab penyakit karang pada pertumbuhan karang jenis Fungia, yaitu Rhytisma acernium yang diisolasi dari karang yang terinfeksi penyakit dark spot disease (Sweet et al. 2013). Mikroorganisme dalam bentuk virus juga diketahui memiliki peran menyebabkan penyakit white plague (Soffer et al. 2013).

Beberapa jenis penyakit tersebut disebabkan oleh bakteri yang bersifat patogen yang bersimbiosis di dalam jaringan karang. Carter (2013) menyebutkan bahwa selain algae hijau zooxanthelae, biota karang juga bersimbiosis dengan bakteri yang terdapat di dalam jaringan tubuhnya maupun pada lingkungan perairan. Lebih dari 10.000 jenis bakteri diketahui bersimbiosis dalam sedimen, terumbu, maupun di dalam jaringan karang itu sendiri (coral tissue) (Carter 2013). Sebagai contoh bakteri Alteromanadaceae, Amoebophilus, Endozoicomonas, Flavobacteriaceae, Cryomorphaceae, dan Methylobacteriaceae bersimbiois pada mucus, dan skeleton karang (Pollock et al. 2018). Jenis bakteri tersebut dapat bersifat menguntungkan maupun merugikan. Bakteri yang merugikan inilah yang bersifat patogen dan menyebabkan penyakit pada karang. Sebagai contoh, bakteri jenis Myroides odoratimimus, Bacillus algicola, dan Marine Alcaligenaceae bacterium merupakan bakteri penyebab penyakit black band (BBD) pada karang Acropora di Karimun Jawa Jawa Tengah (Sabdono et al. 2015).

Penyakit purple syndrome (PS) pada biota karang sangat jarang ditemukan kasusnya di dunia. Kasus infeksi penyakit karang PS pernah ditemukan di perairan Pulau Panjang, Jepara Jawa Tengah dengan nilai prevalensi penyakit sebesar 23\% (Sawonua 2016). PS diidentifikasi secara morfologi sebagai bercak tidak beraturan berwarna ungu pada skeleton 
karang. Beberapa peneliti menyebutkan kemiripan penampakan antara PS dengan dark spot syndrom (Randall et al. 2016). Lebih lanjut Randall et al. (2016) mengemukakan dark spot syndrome dicirikan dengan luka berupa bercak berwarna ungu sampai dengan kecoklatan dan hilangnya jaringan karang. Kedua penyakit tersebut sampai saat ini belum diketahui agen penyebabnya apakah dikarenakan mikroorganisme ataukah karena stress pada karang (Kellogg et al. 2014). Penamaan dalam suatu penyakit karang biasanya merujuk pada beberapa hal, seperti nama itu diberikan berdasarkan pengamatan tunggal (single observation). Sebagai contoh penyakit white blotch, yellow blotch, white syndrome, black and purple spots, atau yellow to white spots. Selain itu penamaan penyakit juga dapat berdasarkan tanda-tanda visual yang nampak pada karang yang terinfeksi penyakit seperti pada white band disease, black band disease, dan yellow band disease. Penelitian ini bertujuan untuk mengidentifikasi jenis bakteri patogen penyebab penyakit PS pada karang Fungia curvata.

\section{BAHAN DAN METODE}

\section{Waktu dan lokasi penelitian}

Penelitian ini dilaksanakan dalam dua tahap, yaitu pengambilan sampel karang Fungia curvata di perairan Pulau Hari Sulawesi Tenggara pada bulan Mei 2017 (Gambar 1). Tahap kedua yaitu sampel karang dianalisis secara mikrobiologi selama 4 bulan (Juni-September 2017) di Laboratorium Pengujian Fakultas Perikanan dan IImu Kelautan Universitas Halu Oleo, Kendari, Sulawesi Tenggara.

\section{Alat dan bahan \\ Alat dan bahan dalam penelitian ini dikategorikan menjadi alat dalam pengambilan sampel di lapangan serta alat dan bahan dalam analisis labolatorium. Pengambilan sampel karang dilakukan dengan menggunakan alat scuba diving, Gobal Positioning System (GPS), kamera bawah air, plastik sampel, dan cool box. Alat labolatorium yang digunakan untuk kultur bakteri berupa autoclave, cawan petri, tabung reaksi, vortex. Uji antagonistik menggunakan alat shaker dan cawan petri untuk melakukan}

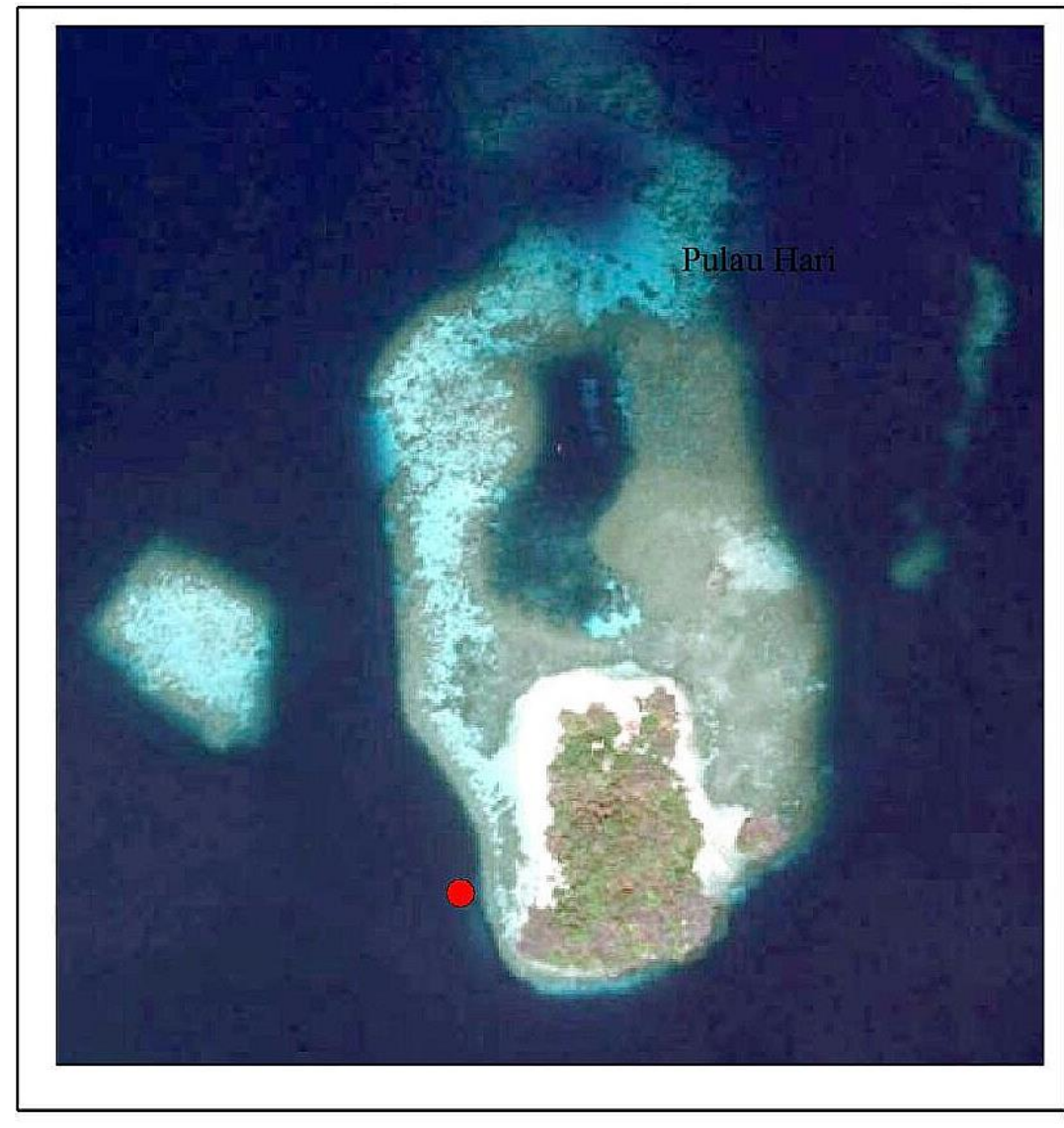

Gambar 1. Peta pengambilan sampel karang Fungia
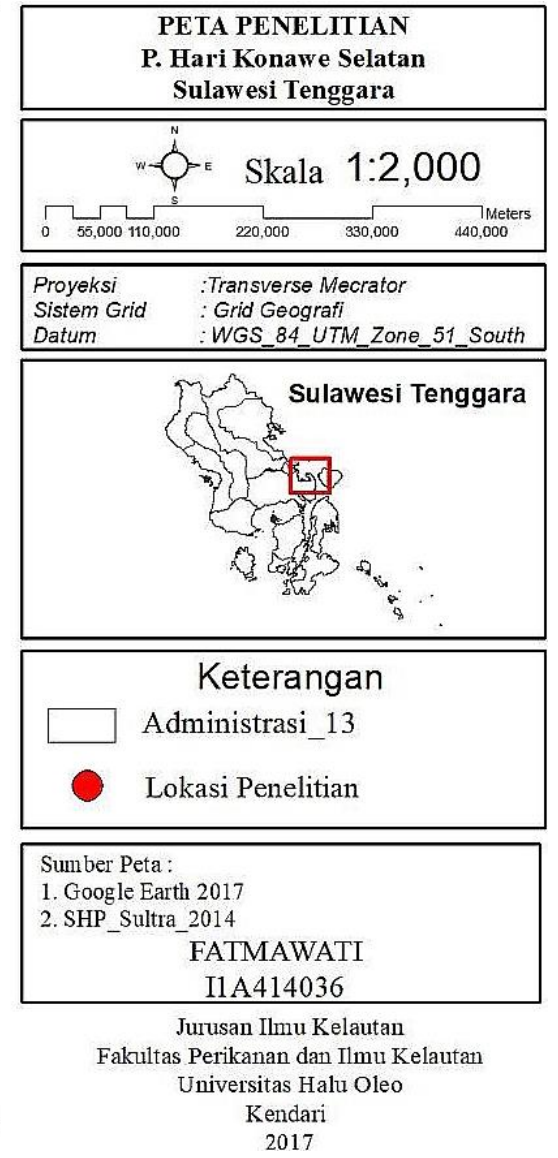
pengujian. Uji Postulat Koch menggunakan akuarium $(6 \times 30 \times 35 \mathrm{~cm})$ dan syringe untuk menyuntik bakteri ke jaringan karang. PCR menggunakan Elfor (Clever Scientific, Thermal Cycler T100 Biorad), Uvi-doc (Cambridge Uvi-doc). Bahan yang digunakan untuk membuat media bakteri air laut yaitu media Zobell yang terdiri dari Agar HIMEDIA GRM026, Pepton OXOID LP0034, dan Yeast OXOID LP0034. Bahan untuk PCR agarose (Biorad 1\%) dan buffer TBE (Biorad). Sampel karang uji yang digunakan dari jenis Fungia curvata.

\section{Metode}

Metode penelitian menggunakan deskriptif eksploratif yang terdiri dari dua tahap. Tahap pertama dilakukan di perairan laut yang bertujuan untuk mengambil sampel karang terinfeksi PS. Tahap kedua adalah analisis laboratorium yang terdiri dari isolasi, purifikasi, uji antagonistik, serta uji Postulat Koch. Hasil dari uji Postulat Koch selanjutnya dilakukan uji biomolekuler untuk mengetahui jenis bakteri sampai dengan ke tingkat spesies.

\section{Pengambilan sampel karang}

Tahapan pertama bertujuan untuk pengambilan sampel jaringan karang berpenyakit atau karang yang sudah terinfeksi penyakit PS. Sampel karang Fungia diambil di Perairan Pulau Hari Sulawesi Tenggara dengan bantuan scuba diving. Pengambilan karang dilakukan dengan metode koleksi bebas pada kedalaman kurang lebih $7 \mathrm{~m}$. Sampel karang terinfeksi penyakit PS diambil dengan lebar sekitar 5 $\mathrm{cm}$ atau satu individu karang (Gambar 2). Perlakuan karang sebelum dianalisis laboratorium adalah dimasukkan ke dalam plastik sampel yang berisi air laut, selanjutnya dimasukkan kedalam cool box yang telah berisi es batu. Tujuannya adalah untuk melemahkan biota karang (pingsan) sehingga biota karang tidak mengalami stress selama perjalanan.

\section{Isolasi dan purifikasi}

Tahapan selanjutnya adalah isolasi atau penanaman bakteri pada media agar. Metode yang digunakan dalam isolasi bakteri adalah metode sebar (spread method) dengan menggunakan alat spreader (Sabdono 2009). Isolasi bakteri dilakukan dengan menggerus sampel jaringan karang yang terinfeksi dengan menggunakan mortal steril. Selanjutnya sampel diambil sebanyak $1 \mathrm{~g}$ dan diencerkan dengan menggunakan media air laut steril. Pengenceran dilakukan 5 kali $\left(10^{-1}-10^{-5}\right)$. Selanjutnya penanaman bakteri menggunakan 3 pengenceran terakhir $\left(10^{-3}, \quad 10^{-4}\right.$, dan $\left.10^{-5}\right)$. Setiap seri pengenceran tersebut diambil $35 \mu \mathrm{L}$ sampel menggunakan mikropipet dan disebarkan ke dalam media half strength Zobell padat. Selanjutkan diratakan menggunakan spreader dan diinkubasi selama minimal $2 \times$ 24 jam pada suhu ruang $\left(25-27^{\circ} \mathrm{C}\right)$. Pengamatan terhadap koloni bakteri yang tumbuh dicatat dari segi bentuk, warna, pinggiran, dan jumlah koloni sebelum dilakukan pemurnian (purifikasi).

Tahapan kedua adalah purifikasi atau pemurnian bakteri. Tahapan ini bertujuan untuk mendapatkan kultur murni dari bakteri karang. Metode yang digunakan untuk purifikasi adalah metode goresan (streak method) (Sabdono 2009). Masing-masing bakteri yang tumbuh dari koloni berbeda dikultur kembali dengan cara digores zig-zag sampai muncul satu warna (warna yang sama dengan koloni asal). Biakan bakteri yang sudah murni selanjutnya dikultur dalam media cawan dan media miring dalam tabung reaksi. Fungsi penanaman pada media miring adalah untuk mencegah kontaminasi dan dapat digunakan untuk uji selanjutnya.

\section{Uji tantang dan Postulat Koch}

Sebelum dilakukan uji Postulat Koch, terlebih dahulu dilakukan uji tantang (antagonistik) antara masing-masing jenis isolat yang didapatkan pada karang terinfeksi penyakit PS. Metode yang digunakan dalam

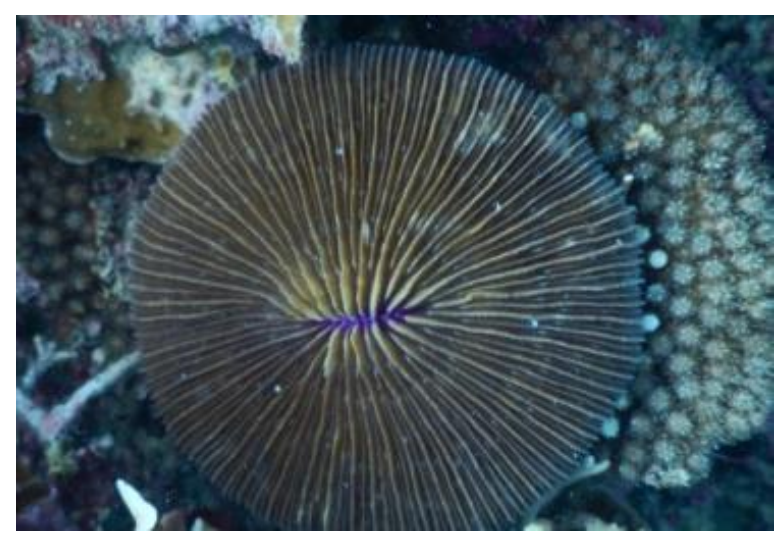

Gambar 2. Foto karang sehat Fungia curvata di Pulau Hari 
uji ini adalah overlay atau uji secara kualitatif melalui pengamatan kemunculan zona hambat atau bening. Uji ini bertujuan untuk mengetahui antagonistik antara isolat satu dengan isolat lainnya yang berguna untuk membuat bakteri konsorsium. Jika terdapat zona hambat atau zona bening, maka bakteri tersebut tidak dapat dikonsorsium atau digabungkan pada saat uji Postulat Koch karena bakteri tersebut akan saling melemahkan.

Uji Postulat Koch dilakukan dengan metode syringe ex situ (dilakukan di laboratorium). Uji ini dilakukan dengan cara mengkultur isolat bakteri konsorsium ke dalam media cair, kemudian diinokulasikan atau disuntikkan ke jaringan karang sehat (Fungia) yang diletakkan dalam akuarium. Karang uji berasal dari tempat yang sama (Pulau Hari) dengan jenis yang sama pula dari karang yang terinfeksi. Perlakuan dilakukan dengan dua kali ulangan dari masing-masing penyakit. Selanjutnya dilakukan pengamatan terhadap karang uji selama kurang lebih $7 \times 24$ jam. Jika terdapat tanda-tanda penyakit PS maka bakteri tersebut positif bersifat patogen atau sebagai penyebab penyakit dan dapat ditingkatkan untuk uji selanjutnya.

\section{Sekuensing bakteri}

Sebelum dilakukan uji sekuensing terhadap bakteri positif patogen, terlebih dahulu dilakukan serangkaian analisis untuk pemurnian DNA. Uji tersebut berupa ekstraksi DNA untuk pemurnian DNA bakteri, Polimerase Chain Reaction (PCR) untuk memperbanyak (amplification) DNA invitro secara enzimatis, dan elektroforesis untuk visualisasi band hasil PCR. Ekstraksi DNA menggunakan metode Chelex 100 (Walsh et al. 2013). PCR menggunakan universal primer 27F (5' AgAgTTTGATCMTGGCTCAG-3) dan 1492R (5' TACGGTTAACCTTGTTACGACTT) dengan komposisi mix PCR menggunakan GoTaq®Green Mix Promega (25 $\mu \mathrm{L})$. Protokol amplifikasi PCR berdasarkan Lee at al. (2007). Sekuensing DNA dengan menggunakan Big Dye Terminator v3.1 dan menggunakan $\mathrm{ABI} 3130 \mathrm{XL}$, sedangkan analisis sekuensing sampel menggunakan Applied Biosystem.

Analisis ini dilakukan di Labolatorium Bioteknologi Laut Tropis FPIK Undip,
Semarang. Sedangkan uji sekuensing dilakukan oleh pihak ketiga, yaitu PT Genetika Science, Jakarta dan $1^{\text {st }}$ Base, Malaysia. Hasil sekuensing dianalisis menggunakan Basic Local Alignment Search Total (Blast) Homologi. Pohon filogenetik menggunakan software Molecular Evolusionary Genetics Analysis (MEGA), Clustal X, dan BioEdit.

\section{HASIL DAN PEMBAHASAN}

Secara umum tipe terumbu karang di perairan Pulau Hari adalah karang tepi (fringing reef). Pulau tidak berpenghuni ini masuk dalam Kawasan Konservasi Perairan Daerah (KKPD) yang ditetapkan sejak Tahun 2017, yaitu masuk dalam KKPD Teluk Starling. Sampai dengan Tahun 2016 persentase tutupan karang hidup di pulau tersebut sebesar $49 \% \pm 6.35 \%$ atau masuk dalam kondisi sedang (Sartin et al. 2016). Salah satu jenis karang yang melimpah di pulau ini adalah karang Fungia dengan bentuk pertumbuhan coral mushroom (CMR) (Gambar 2). Karang dengan bentuk pertumbuhan jamur (mushroom) merupakan karang soliter yang dapat ditemukan hampir merata di spot diving Pulau Hari dengan distribusi sampai kedalaman $8 \mathrm{~m}$. Selain CMR, bentuk pertumbuhan karang yang ditemukan di perairan Pulau Hari meliputi acropora branching (ACB), coral massive (CM), coral foliose (CF), coral submassive (CSM), dan coral encrusting (CE) (Fauzan 2014).

Penyakit karang karena infeksi mikroorganisme sudah menjadi perhatian dalam pengelolaan ekosistem terumbu karang. Salah satu hal yang mengkhawatirkan adalah adanya menyebaran infeksi bakteri oleh hewanhewan pemakan karang (corallivorous) khususnya pada ikan karang sebagai penyebab penyebaran inveksi ke karang sehat (Raymundo et al. 2009). Sebagai contoh ikan kakatua, siput drupella, maupun ikan kepe-kepe. Lebih lanjut Chong-Seng et al. (2011) menjelaskan kontribusi ikan pemakan karang ini dapat menyebarkan penyakit melalui gigitan karang yang terinveksi bakteri patogen. Apabila Ikan tersebut memakan jaringan karang sehat akhirnya bisa terkena inveksi bakteri dan menyebabkan penyakit karang. Hal lain yang 
Tabel1. Hasil identifikasi morfologi koloni bakteri yang bersimbiosis pada karang terinfeksi purple syndrome (PS) pada karang Fungia curvata

\begin{tabular}{clccc}
\hline \multirow{2}{*}{ No. } & $\begin{array}{l}\text { Kode } \\
\text { Isolat }\end{array}$ & \multicolumn{3}{c}{ Morfologi } \\
\cline { 3 - 5 } & PSMH1 & putih & lonjong & berinti \\
\hline 2 & PSMH2 & putih & $\begin{array}{c}\text { tak } \\
\text { beraturan }\end{array}$ & berinti \\
\hline 3 & PSMH3 & putih & bundar & berinti \\
\hline 4 & PSMH4 & orange & bundar & berinti \\
\hline 5 & PSMH5 & $\begin{array}{l}\text { kream- } \\
\text { orange }\end{array}$ & lonjong & tak berinti \\
\hline
\end{tabular}

Keterangan: PS (purple syndrome); M (bentuk pertumbuhan karang); $\mathrm{H}$ (Pulau Hari); $1,2,3,4$ dan 5 (kode isolat)

perlu diwaspadai adalah fenomena bleaching atau pemutihan karang akibat kenaikan temperatur. Penelitian Miller et al. (2009) di Pulau Virgin Amerika Serikat menyatakan bahwa terdapat kecenderungan munculnya penyakit karang setelah kejadian coral bleaching.

Karang Fungia yang terinfeksi PS dalam penelitian ini diambil di laut pada kedalaman 7 $\mathrm{m}$. Penyakit PS ini dapat diidentifikasi secara visual dengan gejala terdapat bercak berwarna ungu berupa lesi pada karang yang terinfeksi (Gambar 3). Berdasarkan hasil isolasi dan purifikasi didapatkan 5 (lima) isolat bakteri yang berasosiasi dengan karang

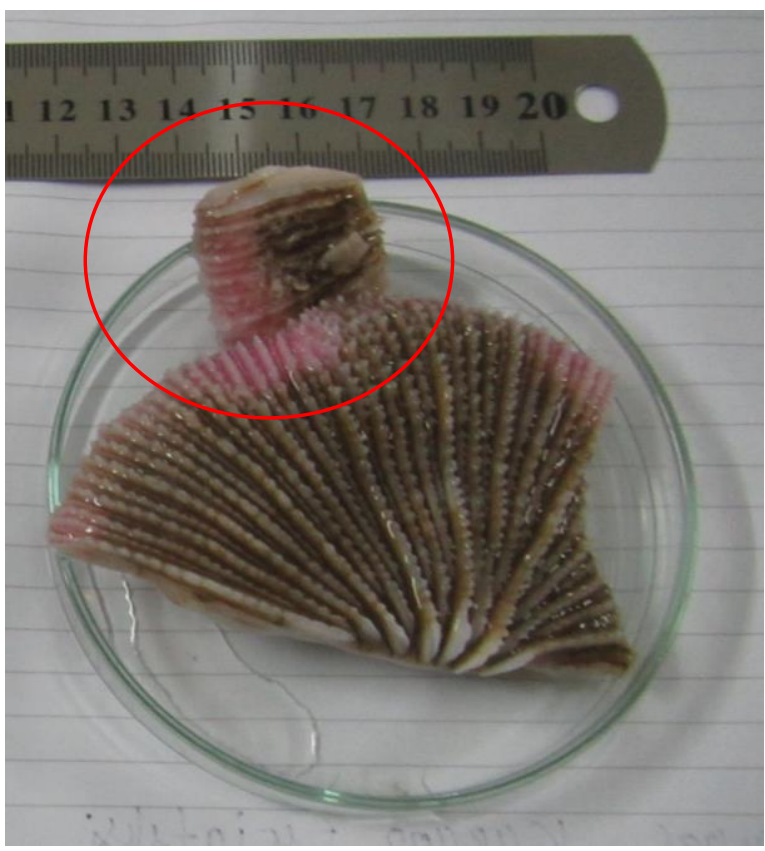

Gambar 3. Contoh jaringan karang Fungia yang terinfeksi penyakit Purple Syndrome (lingkaran merah) di Pulau Hari terinfeksi dengan kode isolat $\mathrm{PSMH}$, PSMH2, PSMH3, PSMH4, dan PSMH5 (Gambar 4). Identifikasi visual dari bakteri ini dapat dilihat pada Tabel 1. Berdasarkan Tabel 1 dapat dilihat identifikasi berdasarkan warna cenderung hampir sama, yaitu berwarna putih sedangkan berdasarkan elevasi hampir semua isolat berinti ( 1 isolat
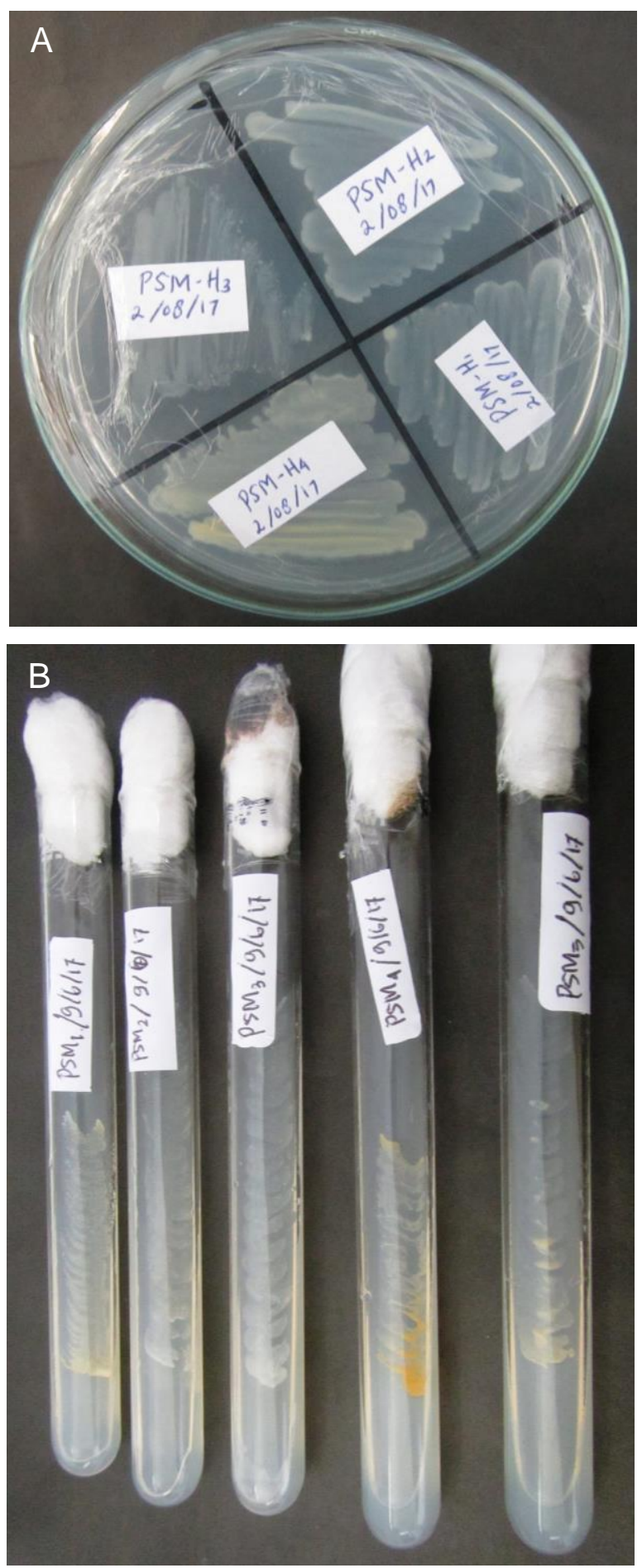

Gambar 4. Isolat murni dari bakteri simbion karang terinfeksi PS dalam media cawan (A) dan media miring $(\mathrm{B})$ 
Tabel 2. Hasil sekuensing DNA bakteri patogen PS

\begin{tabular}{cccccc}
\hline No & Kode Isolat & $\begin{array}{c}\text { Pajang Nukleotida } \\
\text { (bp) }\end{array}$ & Kekerabatan Terdekat (sp) & Similarity & $\begin{array}{c}\text { Accession Number } \\
\text { (BLAST) }\end{array}$ \\
\hline 1 & MH2/ PSMH2 & 1387 & $\begin{array}{c}\text { Enterobacter cloacae subsp. } \\
\text { dissolvens strain LMG 2683 }\end{array}$ & $99 \%$ & NR_044978 \\
2 & MH4/ PSMH4 & 1388 & $\begin{array}{c}\text { Enterobacter cloacae subsp. } \\
\text { dissolvens strain ATCC 23733 }\end{array}$ & $99 \%$ & NR_044978 \\
\hline
\end{tabular}
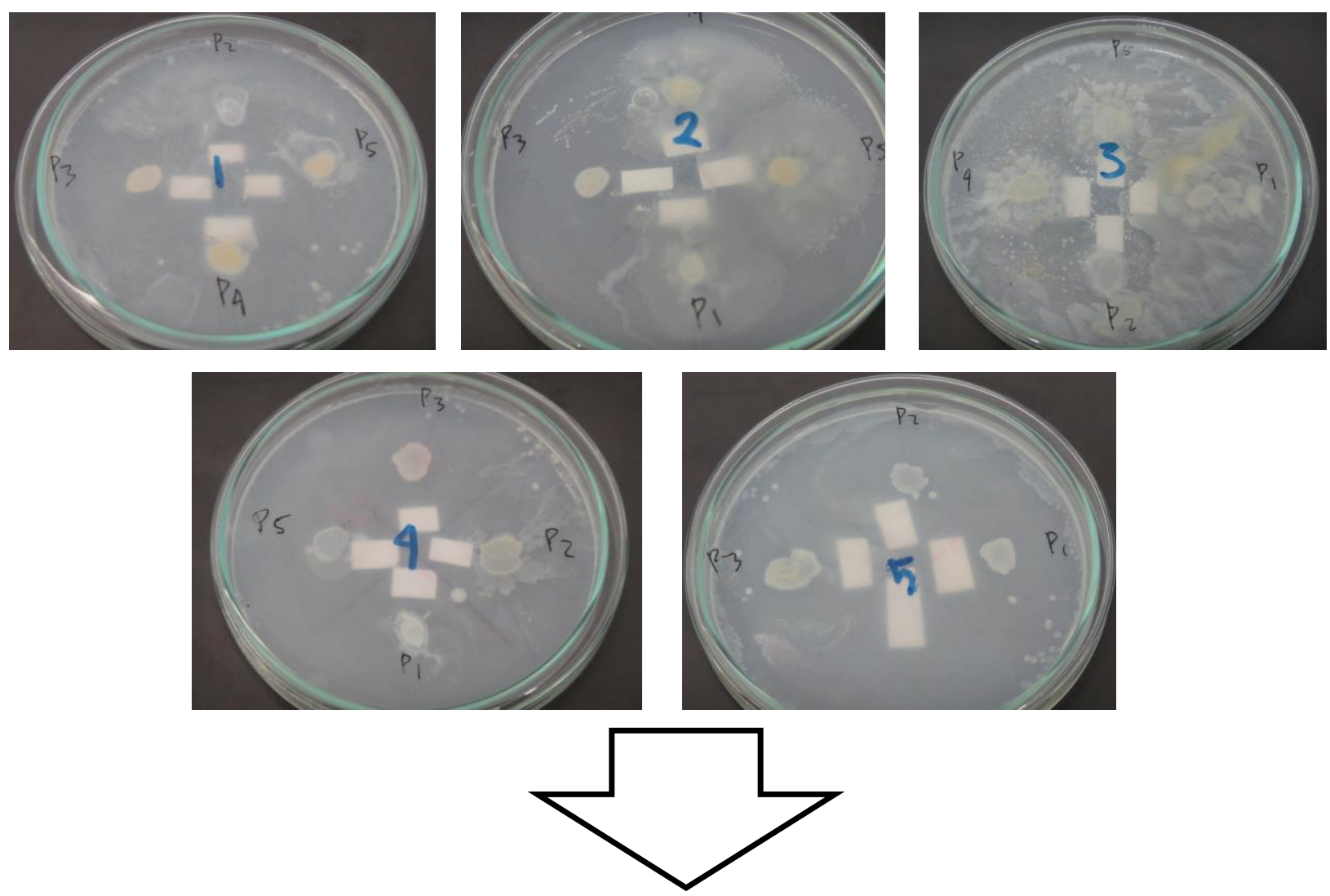

A
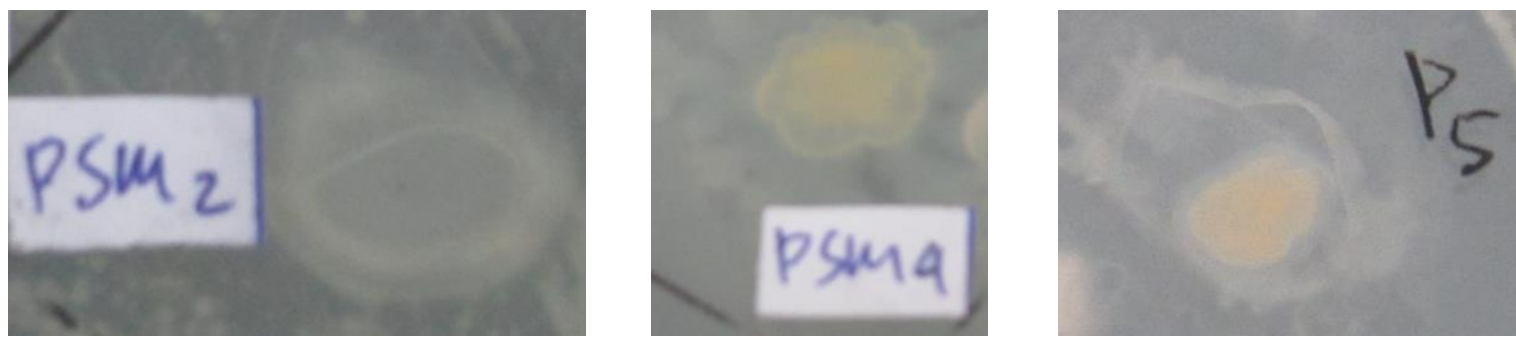

B
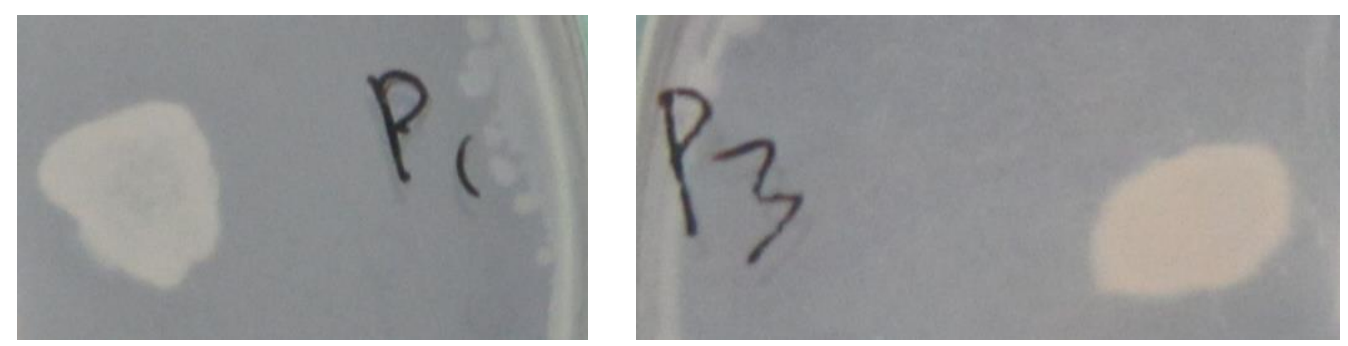

Gambar 5. Uji tantang antar bakteri pada karang terifeksi purple syndrome 
tidak mempunyai inti). Kelima kode bakteri ini merupakan koloni murni dan masih belum diketahui jenis patogenitasnya positif atau negatif. Hasil isolasi dan purifikasi bakteri yang terinfeksi ini lebih sedikit jika dibanding dengan penelitian Sawonua (2016) di Pulau Panjang, Jepara Jawa Tengah dengan jenis penyakit yellow blotch yaitu 8 isolat.

Selain zooxanthellae, mikroorganisme jenis bakteri laut dapat bersimbiosis dengan biota karang. Mikroorganisme ini hidup dalam jaringan mucus, jaringan dalam (indodermis), sampai dengan hidup dalam terumbu biota karang (Ayuningrum et al. 2017). Lebih lanjut dijelaskan bahwa diantara ketiga tempat tersebut, simbion bakteri banyak terdapat dalam jaringan mucus karang. Hal ini dikarenakan jaringan mucus atau jaringan lendir banyak mengandung mucopolysaccharide yang merupakan nutrisi bagi bakteri.

Berdasarkan uji antagonistik, 2 isolat bakteri dapat dikonsorsium yaitu kode isolat PSMH1 dan PSMH3. Identifikasi bakteri ini adalah tidak terdapat zona bening disekitar
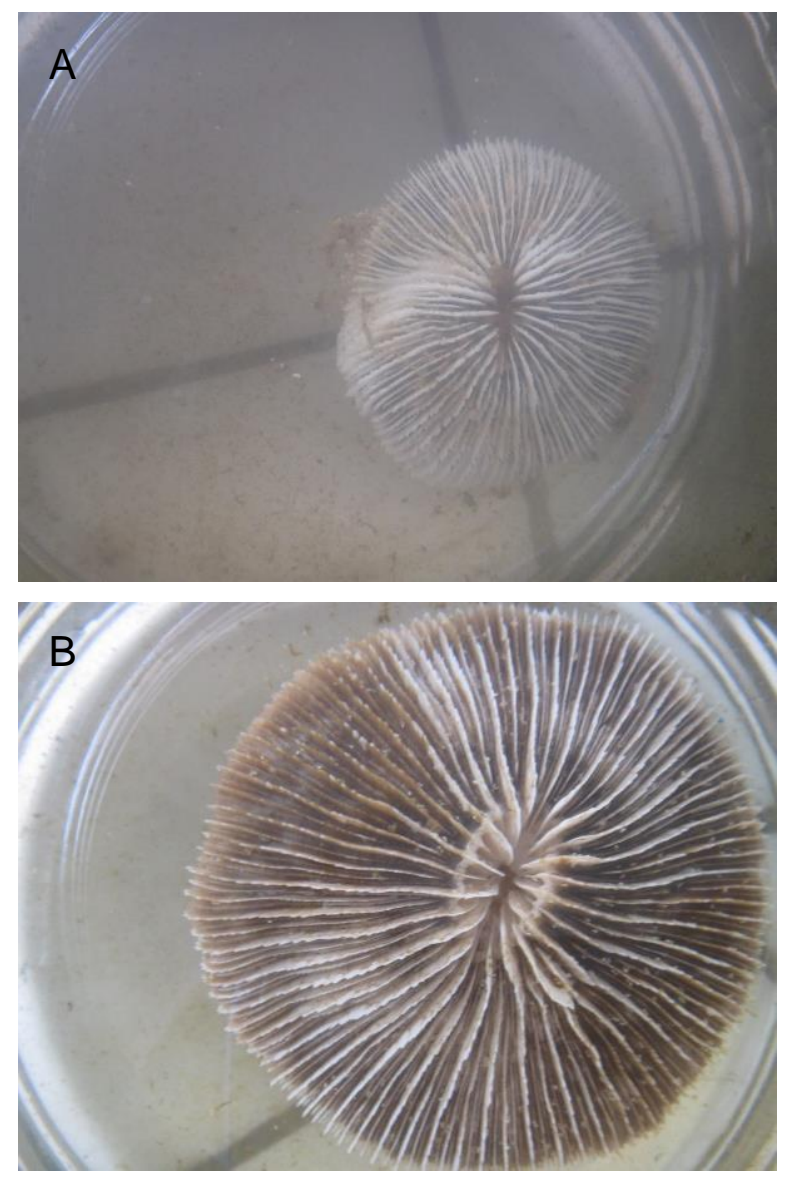

Gambar 6. Hasil Uji Postulat Koch. Karang yang terinveksi PS: PSMH4 (A) dan PSMH2 (B) koloni bakteri yang ditanam (Gambar 5b). Sebaliknya kode isolat PSMH2, PSMH4, dan PSMH5 merupakan bakteri yang tidak dapat dikonsorsium. Hal tersebut ditandai dengan adanya kemunculan zona bening disekitar koloni bakteri yang ditanam (Gambar 5a).

Berdasarkan uji Postulat Koch dari kelima jenis bakteri didapatkan 2 jenis isolat yang berpotensi patogen, yaitu kode isolat PSMH2 dan PSMH4. Hal ini diketahui pada akhir uji Postulat Koch, yaitu karang uji mengalami kematian dengan tanda-tanda visual menunjukkan gejala PS (Gambar 6). Berdasarkan gambar tersebut tampak karang Fungia sudah memutih dan kehilangan skeleton jaringan karangnya. Gambar tersebut merupakan pengamatan hari ke-14 setelah karang diinjeksi bakteri.

Selanjutnya dua isolate bakteri yang berpotensi patogen (PSMH2 dan PSMH4) dilakukan uji biomolekuler. Visualisasi elektroforesis dari ekstraksi DNA bakteri pathogen $\mathrm{PS}$ dengan kode isolat $\mathrm{MH} 2$ untuk $\mathrm{PSMH} 2$, dan $\mathrm{MH} 4$ untuk PSMH4 dapat dilihat pada Gambar 7. Berdasarkan gambar tersebut diketahui ketebalan band yang bisa dilakukan sekuensing berada pada 1500 bp.

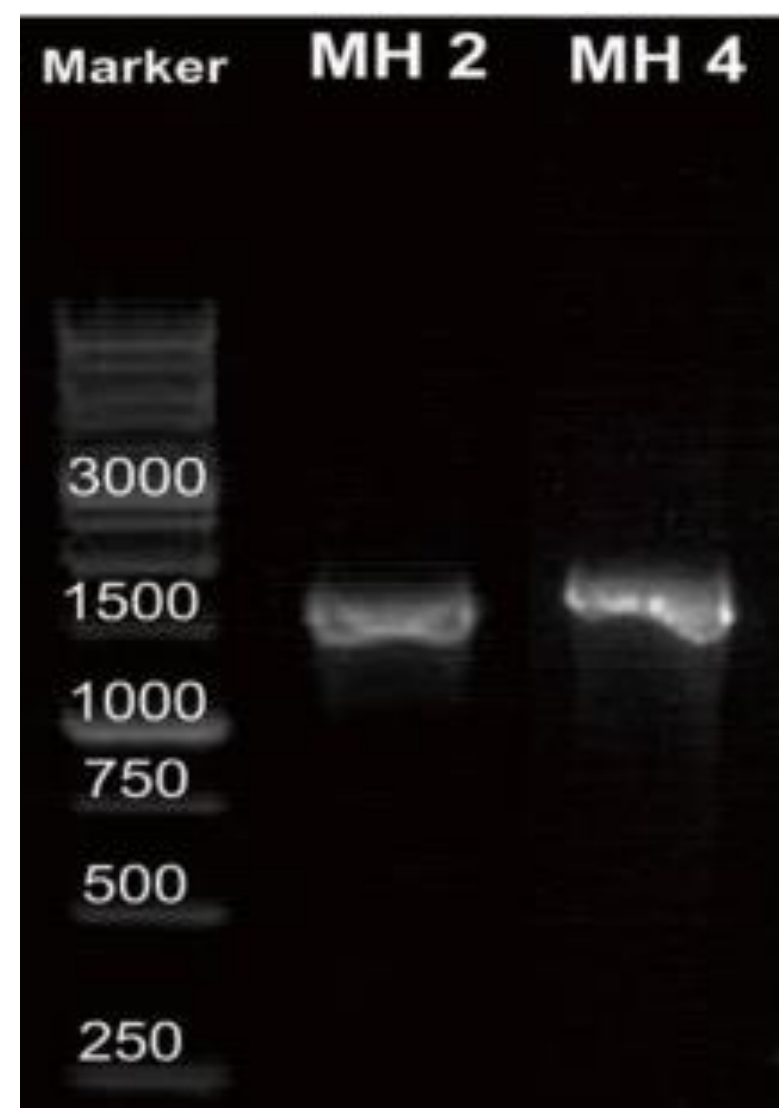

Gambar 7. Visualisasi band DNA bakteri pathogen purple syndrome 
Selanjutnya hasil sekuen DNA diperbandingkan dengan menggunakan pustaka sekuen bakteri yang tersimpan dalam database GenBank. Hasil analisis BLAST dan pohon filogenetik menunjukkani solat PSMH2 dan PSMH4 adalah anggota strain Enterobacter cloacae (accession number GenBank NR_044978) dengan tingkat kekerabatan sebesar $99 \%$ (Tabel 2 dan Gambar 8).

Bakteri jenis Enterobacter cloacae merupakan spesies dari Family Enterobacteriaceae. Anggota Family ini terdiri dari 53 genera dan lebih dari 170 jenis spesies (PHE, 2015). Sebagian besar anggota dari Family Enterobacteriaceae merupakan bakteri gram negatif, melakukan pergerakan dengan flagellata, dan hidup optimum pada suhu $37^{\circ} \mathrm{C}$, meskipun ada juga beberapa spesies yang hidup pada suhu 25 $30^{\circ} \mathrm{C}$. Bakteri jenis Enterobacter cloacae banyak tersebar di alam, hidup dalam tanah, air, maupun dalam tubuh manusia dan hewan (PHE, 2015). Penelitian yang relevan dilakukan oleh Babu et al. (2004) dan lyer et al. (2005) dengan bakteri jenis yang sama (Enterobacter cloacae) bersimbiosis pada karang Acropora sp. di Teluk Mannar India dan ditemukan pada sedimen laut di pantai Gujarat India. Lebih I anjut penelitian

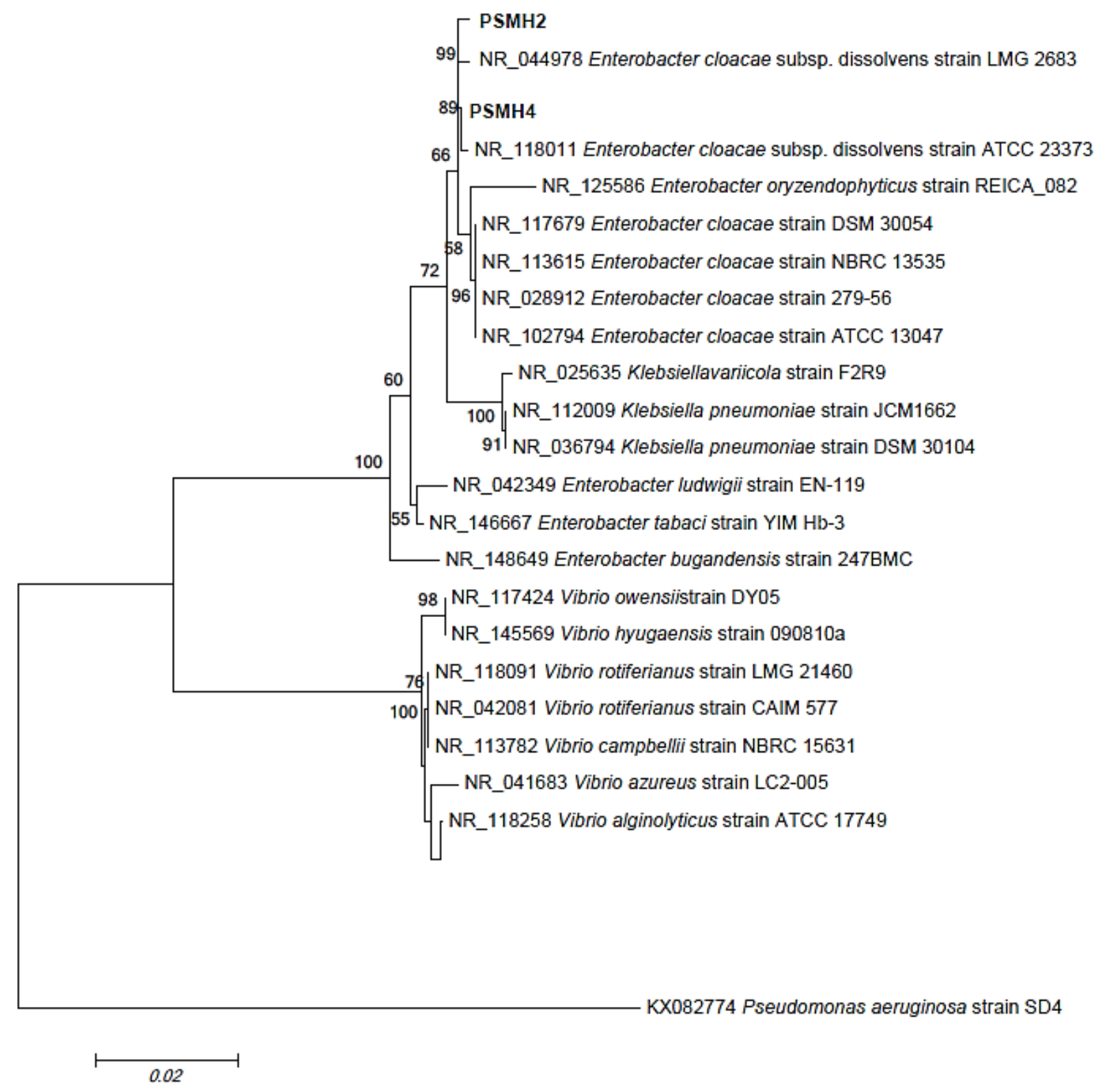

Gambar 8. Pohon filogenetik dari isolat PSHM2 dan PSHM4 
Ayuningrum et al. (2017) mengungkapkan bakteri genus Enterobacter sp. Merupakan jenisbakteri multi-drug resistant (MDR), yaitu penyebab kematian beberapa kasus di Indonesia. Penelitian Poopathi et al. (2013) yang dilakukan pada sedimen laut menunjukkan strain dari Enterobacter cloacae VCRC-B519 memiliki potensi dalam mensintesis protein dan menghasilkan toksin.

Lebih lanjut Arulazhagan et al. (2010) dalam penelitiannya mengisolasi bakteri dari lingkungan laut menyebutkan bahwa bakteri jenis Enterobacter cloacae mengandung senyawa organic polycyclic aromatic hydrocarbons dan bersifat halotoleran atau bakteri yang dapat mentoleransi salinitas tinggi. Jenis senyawa polycyclic aromatic hydrocarbons bersifat toksik dan beberapa bakteri yang masuk dalam jenis halotoleran mempunyai spora yang bersifat patogen. Diduga pathogen atau toksik yang dikeluarkan oleh bakteri yang bersimbiosis di jaringan karang menyebabkan karang uji terkena PS.

Titik lokasi penelitian yang dekat dengan daratan (pesisir) sehingga memungkinkan bakteri pathogen tertransport ke perairan dan menginfeksi biota karang di Pulau Hari. Walaupun Pulau hari merupakan pulau yang tidak berpenghuni dan termasuk dalam pulau kecil di Sulawesi Tengara akan tetapi aktivitas di pulau tersebut cukup padat. Pulau ini selain sebagai tempat persinggahan nelayan dari mencari ikan juga sebagai pulau wisata yang dikunjungi tiap saat. Air buangan limbah kapal serta aktivitas wisata diduga berkontribusi terhadap keberadaan penyakit di Pulau Hari. Castaneda-Chávez et al. (2018) mengemukakan berdasarkan penelitiannya di Caribia dan Teluk Meksiko bahwa kehadiran bakteri patogen di perairan dipengaruhi oleh sirkulasi air dalam hal ini pola arus, polusi dari daratan, serta perubahan temperatur yang membuat kenaikan stress pada biota karang.

\section{KESIMPULAN}

Berdasarkan hasil penelitian ini terdapat 5 isolat murni bakteri yang berasosiasi dengan karang yang terinfeksi penyakit purple syndrome. Berdasarkan uji Postulat Koch dan sekuensing DNA jenis bakteri yang berpotensi positif patogen penyebab purple syndrome adalah dari jenis
Enterobacter cloacae dengan tingkat kekerabatan sebesar 99\% dengan kode isolate PSMH2 dan PSMH4.

\section{UCAPAN TERIMA KASIH}

Penulis menyampaikan terimakasih kepada DRPM Direktorat Jenderal Penguatan Riset dan Pengembangan Kemenristek Dikti RI atas hibah penelitian produk terapan dengan nomor kontrak 065/ADD/SP2H/LT/DRPM/VIII/2017.

Terimakasih kepada Tim Pulau Hari (Risfandi, MM; Rahmadani, M.Si; Adha Muhammad, S.Si; dan Aci Alamin, S.Si). Tim analis laboratorium FPIK (Fatmawati, S.Si dan Haris Rafilu, S.Si).

\section{DAFTAR PUSTAKA}

Abrar M, Bachtiar I, Budiyanto A (2012) Struktur komunitas dan penyakit pada karang (Scleractinia) di perairan Lembata, Nusa Tenggara Timur. J IImu Kelautan 17:109-118. doi: 10.14710/ik.ijms.17.2.109-118

Arulazhagan P, Vasudevan N, Yeom IT (2010) Biodegradation of polycyclic aromatic hydrocarbon by a halotolerant bacterial consortium isolated from marine environment. Int J Environ Sci Tech 7:639-652. doi: 10.1007/BF03326174

Ayuningrum D, Kristiana $\mathrm{R}$, Asagabaldan MA, Sabdono A, Radjasa OK, Nuryadi H, Trianto A (2017) Isolation, characterization and antagonistic activity of bacteria symbionts hardcoral Pavona sp. isolated from Panjang Island, Jepara against infectious multidrug resistant (MDR) bacteria. IOP Conf Series: Earth and Environmental Science 55:012029. doi:10.1088/17551315/55/1/012029

Babu TG, Nithyanand P, Kannapiran E, Ravi AV, Pandian KS (2004) Molecular identification of bacteria associated with the coral reef ecosystem of Gulf of Mannar Marine Biosphere Reserve using 16S rRNA sequences. In: Proceedings National Seminar on New Frontiers in Marine Bioscience Research. Alagappa University, Karaikudi, India pp 47-53 
Carter A (2013) Coral's indispensable bacterial buddies. Oceanus 50:6-7

Castaneda-Chávez MR,Lango-Reynoso F, Garcia-Fuentes JL,Reyes-Aguilar AR (2018) Bacteria that affects coral health with an emphasis on the Gulf of Mexico and the Caribbean Sea. Lat Am J Aquat Res 46:880-889. doi: 10.3856/vol46issue5-fulltext-2

Chong-Seng KM, Cole AJ, Pratchett MS, Willis BL (2011) Selective feeding by coral reef fishes on coral lesions associated with brown band and black band disease. Coral Reefs 30:473-481. doi: 10.1007/s00338-010-0707-1

de Castro AP, Araújo SD, Reis AM, Moura $R L$, Francini-Filho RB, Pappas G, Rodrigues TB, Thompson FL, Krüger $\mathrm{RH}$ (2010) Bacterial community associated with healthy and diseased reef coral Mussismilia hispida from eastern Brazil. Microb Ecol 59:658-667. doi: 10.1007/s00248-0109646-1

Fauzan T (2014) Analisis predasi polip karang oleh Acanthaster planci terhadap tingkat kerusakan terumbu karang di pantai Pulau Hari Provinsi Sulawesi Tenggara. Tesis, IPB Bogor

lyer A, Mody K, Jha B (2005) Characterization of an exopolysaccharide produced by a marine Enterobacter cloacae. Indian J Exp Biol 43:467-471. PMID: 15900914

Kellogg CA, Piceno YM, Tom LM, DeSantis TZ, Gray MA, Andersen GL (2014) Comparing bacterial community composition of healthy and dark spotaffected Siderastrea siderea in Florida and the Caribbean. PLoS One 9 (10). doi: 10.1371/journal.pone.0108767

Lee YK, Jung HJ, Lee HK (2007) Marine bacteria associated with the Korean brown alga, Undaria pinnatifida. J Microbiol 44:694-698. PMID: 17205052

Miller J, Muller E, Rogers C, Waara R, Atkinson A, Whelan KRT, Patterson M, Witcher B (2009) Coral disease following massive bleaching in 2005 causes $60 \%$ decline in coral cover on reefs in the US Virgin Islands. Coral Reefs 28:925-937. doi: 10.1007/s00338-009-0531-7

Palupi RD, Rahmadani, Ira (2018) Status of coral health and disease in Kessilampe
Waters, Kendari, South East Sulawesi. J Ilmu Kelautan 23:137-144. doi: 10.14710/ik.ijms.23.3.137-144

PHE (2015) Identification of Enterobacteriaceae. UK standards for microbiology investigations. ID 16 Issue 4. Public Health England, London

Pollock FJ, McMinds R, Smith S, Bourne DG, Willis BL, Medina $M$, Thurber RV, Zaneveld Jr (2018) Coral-associated bacteria demonstrate phylosymbiosis and cophylogeny. Nat Commun 9:4921. doi: 10.1038/s41467-018-07275-x

Poopathi S, Ahangar NA, Thirugnanasambantham KK, Praba LV, Mani C (2013) Isolation and characterisation of a new mosquitocidal bacterium strain of Enterobacter cloacae VCRC-B519 from marine soil. J Biocont Sci Technol 24:158-169. doi: 10.1080/09583157.2013.852652

Randall CJ, Jordán-Garza AG, Muller EM, van Woesik R (2016) Does dark-spot syndrome experimentally transmit among Caribbean corals? Plos One. 11(1). doi:10.1371/journal.pone.0147493

Raymundo LJ, Halford AR, Maypa AP, Kerr AM (2009) Functionally diverse reeffish communities ameliorate coral disease. Proceedings of the National Academy of Sciences. October 2009. doi: 10.1073/pnas.0900365106

Sabdono A (2009) Karakterisasi dan identifikasi bakteri simbion karang Goniastrea aspera resisten terhadap logam berat copper (Cu) dari P. Panjang, Jepara. IImu Kelautan 14:117-125. doi: 10.14710/ik.ijms.14.3.117-125

Sabdono A, Radjasa OK, Ambariyanto, Trianto A, Wijayanti DP Pringgenies D, Munasik (2014) An early evaluation of coral disease prevalence on Panjang Island, Java Sea, Indonesia. J Zoological Research 10:20-29. doi: 10.3923/ijzr.2014.20.29

Sabdono A, Sawonua PH, Kartika AGD, Amelia JM, Radjasa OK (2015) Coral disease in Panjang Island, Java Sea: Diversity of anti-pathogenic bacterial coral symbionts. Procedia Chem $14: 15-21$. doi: 
Sartin J, Prabuning D, Amkieltiela (2016) Pengamatan komunitas bentik dan ikan target di kawasan konservasi perairan daerah Provinsi Sulawesi Tenggara (Teluk Staring), taman wisata alam Teluk Lasolo, dan perairan sekitarnya. WWF-Indonesia

Sawonua PH (2016) Potensi anti-patogen bakteri simbion karang masif terhadap penyakit yellow blotch disease (YBL) di perairan Pulau Panjang, Jepara. Tesis, Universitas Diponegoro, Semarang

Soffer N, Brandt ME, Correa AMS, Smith TB, Thurber RV (2013) Potential role of viruses in white plague coral disease.
The ISME J 8:1-13. doi: 10.1038/ismej.2013.137

Sweet M, Burn D, Croquer A, Leary P (2013) Characterisation of the bacterial and fungal communities associated with different lesion sizes of dark spot syndrome occurring in the coral Stephanocoenia intersepta. PLoS One 8:e62580. doi: 10.1371/journal.pone.0062580

Walsh PS, Metzger DA, Higuchi R (2013) Chelex 100 as a medium for simple extraction of DNA for PCR-based typing from forensic material. BioTechniques 54: 134-139. doi: 10.2144/000114018 